\author{
Article \\ Doi 10.5943/mycosphere/8/10/17 \\ Copyright $\odot$ Guizhou Academy of Agricultural Sciences
}

\title{
What is the best: A four marker phylogenetic study of the dark- spored myxomycete Fuligo septica
}

\section{Hoppe T}

Roswitha-Gymnasium, Bismarckstr. 17, D-38678 Bad Gandersheim, GERMANY

Hoppe T 2017 - What is the best: A four marker phylogenetic study of the dark spored myxomycete Fuligo septica Mycosphere 8(10), 1975-1983, Doi 10.5943/mycosphere/8/10/17

\begin{abstract}
Myxomycetes are mono-cell eukaryotic protists with a sexual and asexual life cycle. A morphological system was established within the last 200 years and most of the species are easily distinguishable. During the last decades, however, a number of gene sequences have been made available for many myxomycete species with different gene markers. Forty-three specimens of the myxomycete species Fuligo septica, including its three varieties, were used for a comparison of phylogenetic relations with four different gene markers namely: (i) elongation factor-1alpha (EF1alpha), (ii) small ribosomal subunit (18S rRNA), (iii) ribosomal internal transcribed spacer (ITS2) and (iv) mitochondrial small ribosomal subunit (mtSSU). Phylogenetic trees calculated for the four different gene markers all showed similar results. Haplotype networking for the gene markers showed differences between the networks of the different varieties for the $18 \mathrm{~S}$ rRNA and mtSSU, but not for EF-1alpha and ITS2.
\end{abstract}

Key words - 18S rRNA - EF-1alpha - ITS2 - haplotype analyses - morphological analysis mtSSU - population study

\section{Introduction}

Myxomycetes, also called slime molds, have a worldwide distribution. These organisms are characterized by a multinucleated one-cell plasmodia and a resistant fruiting body. The life cycle can be divided into a haploid and a diploid part (Stephenson 2011). In both parts, a multiplication of the cell is possible. Within a short time, a large population of the same best adapted genotype can expand. This possibility allows these organisms to establish rapidly in a variety of habitats (El Hage et al. 2000). Consequently, many of the species described have a worldwide distribution. Myxomycetes are heterothallic or/and non-heterothallic (Clark \& Haskins 2010) depending on the available environmental conditions. A good example would be the species Fuligo septica that has a typical representative of the asexual and sexual life cycles (Hoppe \& Kutschera 2010). A haploid spore produces an amoeba. They divide mitotically and have predatory roles in soils (Hoppe \& Kutschera 2015). A fusion event of two haploid myxamoeba (apomixes) generates diploid plasmodia. The negative phototactic plasmodia feed on organic materials and change the behavior for fruit body (aethalia) development into a positive phototactic one. First, the diploid nuclei are enclosed in one spore. Here they are converted by means of reduction division in a haploid state.

There are five orders of myxomycetes, which have been widely been studied as a large group. From population studies of morphological and molecular-genetic characters became clear that this 
organismic group is heterogenic (Nandipati et al. 2012, Winsett \& Stephenson 2011). Therefore, we used the common species Fuligo septica, with its known varieties, to examine its population structure. The genus Fuligo is placed in the order Physarales. It is characterized by very large yellow, rarely white plasmodia (phaneroplasmodia). An important characteristic of Fuligo septica are the brown spores of less than 8-10 $\mu \mathrm{m}$ in diameter (Table 1, Poulain et al. 2011).

Table 1 - Identification guide of the genus Fuligo.

\begin{tabular}{|c|c|c|c|}
\hline 1 & Cortex spongiose & & 2 \\
\hline $1 *$ & Cortex smooth, rough & & 7 \\
\hline 2 & Spore $6-10 \mu \mathrm{m}$ & & 3 \\
\hline $2 *$ & Spore $10-22 \mu \mathrm{m}$ & & 4 \\
\hline 3.1 & Cortex yellow and calcareous nodes white & F. septica var. septica & \\
\hline 3.2 & Cortex and calcareous nodes white & F. septica var. candida & \\
\hline 3.3 & $\begin{array}{l}\text { Cortex and calcareous nodes yellow, older collections show color only at regions } \\
\text { between cortex to substrat }\end{array}$ & F. septica var. flava & \\
\hline 3.4 & Cortex and calcareous nodes purple & F. septica var. rosea & \\
\hline 3.5 & Cortex white to purpel or red, calcareous nodes purpel, smaller spores & F. septica var. rufa & \\
\hline 4 & Spore $10-13 \mu \mathrm{m}$ & & 5 \\
\hline $4^{*}$ & Spore $14-22 \mu \mathrm{m}$ & F. megaspora & \\
\hline 5 & Cortex yellow, Spore oval & F. licentii & \\
\hline $5^{*}$ & Spore nodular & & 6 \\
\hline 6 & Aethalium more than $10 \mathrm{~mm}$, calcareus nodes white & F. intermedia & \\
\hline $6^{*}$ & Aethalium mostly max. $10 \mathrm{~mm}$, calcareus nodes yellow & F. muscorum & \\
\hline 7 & $\begin{array}{l}\text { Aethalium white, calcareus nodes white, spore oval, } 10-12 \times 14-17 \mu \mathrm{m} \text {, spore } \\
\text { ornamentation net-like }\end{array}$ & F. cinerea & \\
\hline $7 *$ & $\begin{array}{l}\text { Aethalium coloured, spore ornamentation without network-structure } \\
\text { Aethalium yellow, calcareus nodes white, spore oval, smooth with few humps, } 7\end{array}$ & & 8 \\
\hline 8 & x $8-10 \mu \mathrm{m}$ & F. luteonitens & \\
\hline $8^{*}$ & Spore nodular with small humps & & 9 \\
\hline 9 & Aethalia yellow & & 10 \\
\hline $9 *$ & Aethalia red-brown, spore $7-10 \mu \mathrm{m}$, & F. leviderma & \\
\hline 10 & Spore mass black, spore equally-dyed & F. aurea & \\
\hline $10^{*}$ & Spore mass black-brown, spore lopsided brightened, spores smaller than $10 \mu \mathrm{m}$ & F. laevis & \\
\hline
\end{tabular}

At present Fuligo has five varieties and the cortex and the calcareous nodes are important features to distinguish them. The species may have a yellow, white or pink aethaloid fruiting bodies. Fuligo septica var. candida (Fig. 1A) quickly loses the pigmentation after the fruit body matures. The pigment and the lime of the cortex and the pseudocolumella is clearly recognizable. The aethalia of $F$. septica var. flava (Fig. 1B) is permanently yellow. The cortex is early dwindling. The pseudocolumella is yellow to colorless. The aethalia of F. septica var. rufa (Fig. 1C) has a pink-white to pink-brown aethalia. The pseudo-capillitium is white to pink. The spores of these subspecies are significantly smaller than the other varieties. The investigated strains were described as heterothallic and non-heterothallic (Clark \& Haskins 2010). In this study with investigate three varieties of Fuligo with molecular data to establish if the varieties are supported.

Due to the wide distribution of this species and the various reproductive strategies, geographic genotypes are hard to determine. A non-heterothallic reproduction allows (in combination with the clonal reproduction of the haploid amoebae) a rapid manifestation of characteristics (genetic expression results in morphological diversity). 

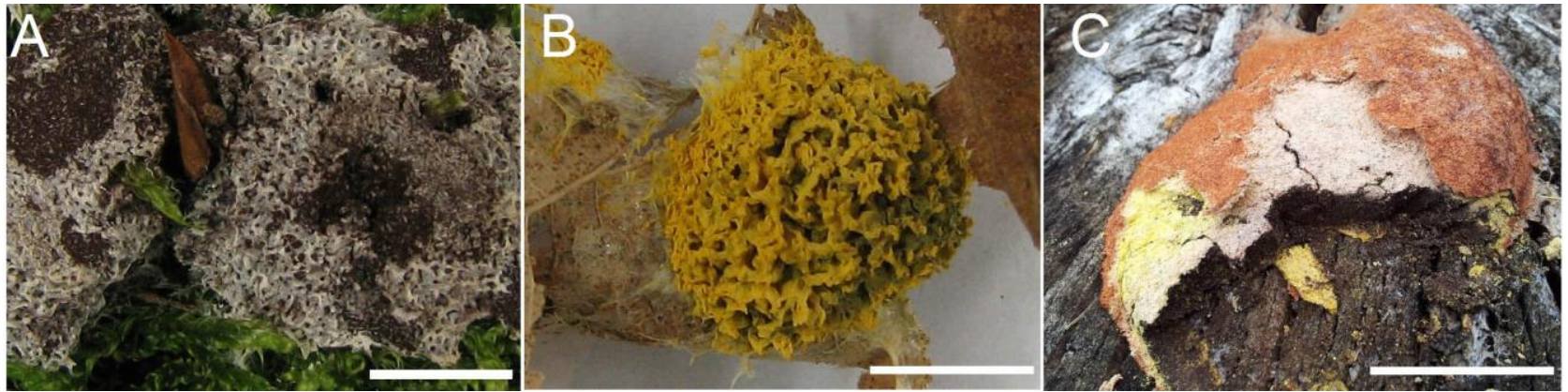

Figure 1 - The investigated varieties: A Fuligo septica var. candida with a typical white cortex, B $F$. septica var. flava with the yellow pigmentation and $\mathrm{C}$ a fresh aethalia of $F$. septica var. rufa with a red pigmentation.

\section{Material and Methods}

Fruiting bodies were sampled in the field or obtained from materials of M. Schnittler (University of Greifswald, Germany), Y. Novozhilov (Russian Academy of Sciences, Russia) and W. Nowotny (Riedau, Austria). Species and variety determinations were carried out using current literatures (Neubert et al. 1995, Poulain et al. 2011).

Morphological characters: Fruiting bodies were measured by light microscope. Spores were air-dried and prepared for scanning electron microscopy (Hoppe \& Kutschera 2010). SEM pictures were taken with a magnification of 2000x. The size of spores and nodes structures were analyzed by the software's AxioVison SE64 (Carl Zeiss Microscopy, Germany). The number of ornaments was measured within a range of $2.4 \mu \mathrm{m}$. The measurement was automated using ImageJ (NIH, Maryland, USA).

Genomic characters: DNA was isolated from 43 aethalia of Fuligo septica. Spores were transferred into an Eppendorf cup and homogenized by using a Ribolyzer (Hybaid, USA). Genomic DNA was extracted with Invisorb Spin DNA Extraction Kit (Stratec Biomedical AG, Germany) according to the manufacturing protocol. PCRs were done for four different gene markers (18S rRNA, EF-1alpha, ITS2 and mitochondrial DNA - mtSSU). Primers used for this study came from different publications or in some instances new primers were designed (Table 2).

Table 2 Used primers for the four investigated gene markers.

\begin{tabular}{llll}
\hline $\begin{array}{l}\text { Gene } \\
\text { Marker }\end{array}$ & Name & Sequence $\left(\mathbf{5}^{\prime} \rightarrow \mathbf{3}{ }^{\prime}\right)$ & Reference \\
\hline 18S rRNA & S3c_F & CTGAATCTGCGWACGGCTCCGC & Hoppe \& Schnittler 2015 \\
& S31_R & AATCTCTCAGGCCCACTCTCCAGG & Hoppe \& Kutschera 2016 \\
EF-1alpha & MYX f3 & CGGAAGCTTTCAAYAARATGGA & Baldauf \& Doolittle 1997 \\
& & CGTCAAGAAGATCGGWTWCAAYCCCGAGAA & \\
& EF-F4D & G & in this study \\
& EF-L3f & GAAGWCCGCYAACCTCSCATGGTACAAGGGA & in this study \\
ITS2 & EF-SF1r & ACACATGGGCTTGGAAGG & Hoppe \& Kutschera 2010 \\
& phf1b & AAAACTCACCAGGTCCRGAT & Kamono \& Fukui 2006 \\
& phf2 & GTCATGCCCTTAGATGTT & Kamono \& Fukui 2006 \\
mtDNA & phr2b & TACAAAGGGCAGGGACGCAT & Kamono \& Fukui 2006 \\
& mtCore 1F & TAGTGTTATTCGTGATGACT & Hoppe 2013 \\
& mtCore 2F & CTCGAATTAAACCACAT & Hoppe 2013 \\
& mtCore_4R & GTTTCKCGCGTTARCTTYAAACC & Hoppe 2013 \\
\hline
\end{tabular}

The PCR-products were sequenced by Beckman Coulter Genomics (GB) and checked by Chromas 2.6 (Technelysium Pty Ltd, Australia, Table 3). 
Table 3 Specimens used in this study.

\begin{tabular}{|c|c|c|c|c|c|c|}
\hline Specimen & $\begin{array}{l}\text { Ref. } \\
\text { Num. }\end{array}$ & Coordinates & 18S rRNA & ITS2 & $\begin{array}{c}\text { EF- } \\
\text { 1alpha }\end{array}$ & mtSSU \\
\hline F. septica & LE254971 & $\mathrm{N} 51^{\circ} 46^{\prime} 10.9 / \mathrm{E} 87^{\circ} 41^{\prime} 3.0$ & KT778649 & KU057879 & KT958794 & KT778618 \\
\hline F. septica var. candida & MYX1415 & $\mathrm{N} 54^{\circ} 02^{\prime} 13 / \mathrm{E} 13^{\circ} 25^{\prime} 44$ & KT778652 & KU057886 & KT958797 & KT778625 \\
\hline F. septica var. candida & MYX1418 & $\mathrm{N} 54^{\circ} 07^{\prime} 37 / \mathrm{E} 13^{\circ} 18^{\prime} 16$ & KT778653 & KU057887 & KT958798 & KT778626 \\
\hline F. septica var. candida & MYX48 & $\mathrm{N} 51^{\circ} 13^{\prime} / \mathrm{E} 8^{\circ} 54^{\prime}$ & KT778656 & KU057880 & FJ546670 & KT778619 \\
\hline F. septica var. candida & MYX490 & N5055'32.9/ E756'33.5 & KT778657 & KU057881 & KT958801 & KT778620 \\
\hline F. septica var. candida & MYX815 & $\mathrm{N} 50^{\circ} 50^{\prime} 36.2 / \mathrm{E} 8^{\circ} 02^{\prime} 22.2$ & KT778659 & KU057883 & KT958803 & KT778622 \\
\hline F. septica var. flava & MYX1452 & N483'ㄴ'15.6/ E8 ${ }^{\circ} 14^{\prime} 20.2$ & KT778655 & KU057889 & KT958800 & KT778628 \\
\hline F. septica var. flava & MYX1043 & $\mathrm{N} 50^{\circ} 56^{\prime} 15.9 / \mathrm{E}^{\circ} 02^{\prime} 28.1$ & KT778660 & KU057890 & KT958804 & KT778629 \\
\hline F. septica var. flava & MYX1044 & N5056'15.9/ E8 $02 ' 28.1$ & KT778661 & KU057891 & KT958805 & KT778630 \\
\hline F. septica var. flava & MYX1172 & $\mathrm{N} 50^{\circ} 50^{\prime} 42.4 / \mathrm{E}^{\circ} 02^{\prime} 27.0$ & KT778662 & KU057892 & KT958806 & KT778631 \\
\hline F. septica var. flava & MYX1226 & $\mathrm{N} 50^{\circ} 50^{\prime} 36.9 / \mathrm{E}^{\circ} 02^{\prime} 25.4$ & KM977866 & KU057893 & KT958807 & KT778632 \\
\hline F. septica var. flava & MYX1234 & $\mathrm{N} 50^{\circ} 50^{\prime} 41.4 / \mathrm{E}^{\circ} 02^{\prime} 27.7$ & KT778663 & KU057894 & KT958808 & KT778633 \\
\hline F. septica var. flava & MYX1235 & $\mathrm{N} 50^{\circ} 50^{\prime} 43.8 / \mathrm{E}^{\circ} 02^{\prime} 23.0$ & KT778650 & KU057884 & KT958795 & KT778623 \\
\hline F. septica var. flava & MYX1240 & $3 / \mathrm{E} 8$ & $\mathrm{KM}$ & 7895 & KT958809 & KT778634 \\
\hline F. septica var. flava & MYX1249 & $\mathrm{N} 50^{\circ} 55^{\prime} 22.7 / \mathrm{E}^{\circ} 56^{\prime} 36.1$ & KP323378 & KU057896 & KT958810 & KT778635 \\
\hline F. septica var. flava & MYX1254 & $\mathrm{N} 50^{\circ} 50^{\prime} 36.2 / \mathrm{E} 8^{\circ} 02^{\prime} 23.5$ & 664 & KU057897 & KT958811 & KT7 \\
\hline F. septica var. flava & MYX1409 & $\mathrm{N} 54^{\circ} 07^{\prime} 47 / \mathrm{E} 13^{\circ} 20^{\prime} 51$ & KT778665 & KU057898 & KT958812 & KT778637 \\
\hline F. septica var. flava & MYX1410 & $\mathrm{N} 54^{\circ} 07^{\prime} 28 / \mathrm{E} 13^{\circ} 18^{\prime} 12$ & 8666 & KU057899 & KT958813 & KT7 \\
\hline F. septica var. flava & MYX1413 & $27 / \mathrm{E} 13^{\circ} 1$ & KT7 & KU057900 & KT958814 & KT7 \\
\hline F. septica var. flava & MYX1414 & $\mathrm{N} 54^{\circ} 07^{\prime} 19 / \mathrm{E} 13^{\circ} 18^{\prime} 16$ & KT778651 & KU057885 & KT958796 & KT778624 \\
\hline F. septica var. flava & MYX1419 & N54 & 54 & 7888 & KT958799 & KT7 \\
\hline F. septica var. flava & MYX1480 & $\mathrm{N} 49^{\circ} 06^{\prime} 01.2 / \mathrm{E}^{\circ} 3^{\circ} 15^{\prime} 03.7$ & 869 & 057901 & KT958815 & KT778640 \\
\hline F. septica var. flava & MYX1519 & N49 $05^{\prime} 56.1 /$ E13 ${ }^{\circ} 13^{\prime} 59.6$ & KM977870 & KU057902 & KT958816 & KT778641 \\
\hline F. septica var. flava & MYX412 & $30.7 / \mathrm{E} 10^{\circ} 49^{\prime} 41.9$ & KT7 & KU057903 & KT958817 & JX125025 \\
\hline F. septica var. flava & MYX458 & $0^{\prime} / \mathrm{E} 8^{\circ} 02^{\prime}$ & KM9 & KU057904 & KT958818 & JX125026 \\
\hline F. septica var. flava & MYX459 & $\mathrm{N} 50^{\circ} 50^{\prime} / \mathrm{E} 8^{\circ} 02^{\prime}$ & KM977872 & KU057905 & KT958819 & JX12 \\
\hline F. septica var. flava & MYX462 & $\mathrm{N} 50^{\circ} 50^{\prime} / \mathrm{E} 8^{\circ} 02^{\prime}$ & KT77 & KU057906 & KT958820 & JX125028 \\
\hline F. septica var. flava & MYX466 & $\mathrm{N} 50^{\circ} 50^{\prime} / \mathrm{E} 8^{\circ} 02^{\prime}$ & KT778670 & KU057907 & KT958821 & JX125029 \\
\hline F. septica var. flava & MYX467 & '/ E8 $8^{\circ} 02^{\prime}$ & KT7 & KU057908 & KT958822 & JX125030 \\
\hline F. septica var. flava & MYX469 & $\mathrm{N} 50^{\circ} 50^{\prime} / \mathrm{E} 8^{\circ} 02^{\prime}$ & KT778672 & KU057909 & KT958823 & JX125031 \\
\hline F. septica var. flava & MYX471 & $\mathrm{N} 50^{\circ} 50^{\prime} / \mathrm{E} 8^{\circ} 02^{\prime}$ & KT778673 & KU057910 & KT958824 & JX125032 \\
\hline F. septica var. flava & MYX482 & $\mathrm{N} 50^{\circ} 50^{\prime} / \mathrm{E} 8^{\circ} 02^{\prime}$ & KT778674 & KU057911 & KT958825 & JX125033 \\
\hline F. septica var. flava & MYX501 & $\mathrm{N} 50^{\circ} 50^{\prime} 35.3 / \mathrm{E} 8$ & KT778675 & KU057912 & KT958826 & JX125035 \\
\hline F. septica var. flava & MYX502 & $\mathrm{N} 50^{\circ} 50^{\prime} 35.5 / \mathrm{E} 8^{\circ} 02^{\prime} 24.1$ & KM9 & KU057913 & KT958827 & JX125036 \\
\hline F. septica var. flava & MYX514 & $\mathrm{N} 51^{\circ} 00^{\prime} 15.4 / \mathrm{E} 8^{\circ} 05^{\prime} 46.2$ & KT778658 & KU057882 & KT958802 & KT778621 \\
\hline F. septica var. flava & MYX525 & N5056'20.3/ E8 $02^{\circ} 59.6$ & KT778676 & KU057914 & KT958828 & JX125038 \\
\hline F. septica var. flava & MYX551 & $\mathrm{N} 51^{\circ} 06^{\prime} 56.8 / \mathrm{E} 8^{\circ} 57^{\prime} 23.9$ & KT778677 & KU057915 & KT958829 & KT778642 \\
\hline F. septica var. flava & MYX602 & N5055'22.4/ E756'35.7 & KT778678 & KU057916 & KT958830 & KT778643 \\
\hline F. septica var. flava & MYX683 & $\mathrm{N} 50^{\circ} 55^{\prime} 20.3 / \mathrm{E} 7^{\circ} 56^{\prime} 45.8$ & KT778679 & KU057917 & KT958831 & KT778644 \\
\hline F. septica var. flava & MYX847 & $\mathrm{N} 50^{\circ} 50^{\prime} 36.7 / \mathrm{E} 8^{\circ} 02^{\prime} 24.8$ & KT778680 & KU057918 & KT958832 & KT778645 \\
\hline F. septica var. flava & MYX865 & $\mathrm{N} 50^{\circ} 50^{\prime} 40.9 / \mathrm{E}^{\circ} 02^{\prime} 48.3$ & KT778681 & KU057919 & KT958833 & KT778646 \\
\hline F. septica var. rufa & MYX1742 & $\mathrm{N} 52^{\circ} 55^{\prime} 15.2 / \mathrm{E} 14^{\circ} 01^{\prime} 37.4$ & KT778682 & KU057920 & KT958834 & KT778647 \\
\hline F. septica var. rufa & MYX372 & $\mathrm{N} 48^{\circ} 18^{\prime} 7.36 / \mathrm{E} 13^{\circ} 38^{\prime} 3.13$ & KM977874 & KU057921 & JF317291 & KT778648 \\
\hline
\end{tabular}

Alignments were made with MEGA 6 analysis software (Tamura et al. 2013). Relations between haplotypes for every marker were constructed with TCS 1.21 (Clement et al. 2000). A neighbor joining tree of a joined alignment was calculated by TOPALI v2.5 (Biomathematics \& Statistics Scotland, GB).

\section{Results}

Phylogenetic trees were constructed for every genetic marker with Neighbor-Joining method and phylogenetic networks for the specimens were estimated (Figs 2-4). 


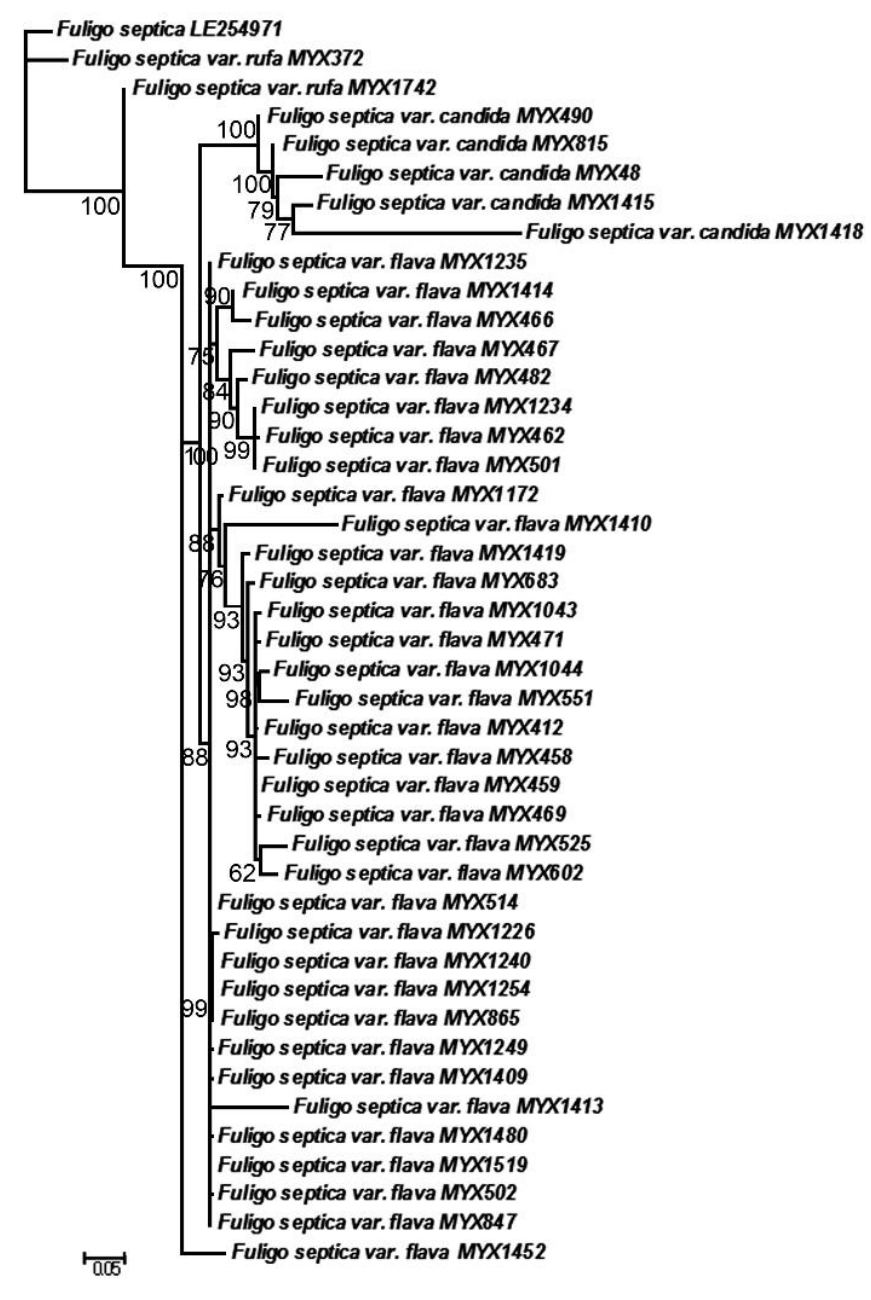

Figure 2 - Phylogenetic tree of the joined alignment from four gene markers (charset=1038bp, 1.000 runs, 1.000 .000 generations, sample freq. 10, burnin 50\%).

The analysis of the individual markers showed similarities to each other and to the morphologic system. The investigated specimens of the three varieties clustered together in similar arrangements. With the combination of the four genetic markers, a combined alignment was constructed and a concatenated tree was calculated (Fig. 2). However, bootstrap values and radiation events are not identical. In all four phylogenies (Fig. 3-4), two major clades within the $F$. septica var. flava are formed. The numerically small groups of $F$. septica var. candida and $F$. septica var. rufa clustered together and the phylogenetic tress of the markers 18S rRNA (Fig. 3A) and mtSSU (Fig. 4B) showed radiation events.

An analysis of the haplotype network for 18S rDNA (Fig. 5A) show three haplotypes of each variety, which are not attached to each other. There are seven haplotypes for $F$. septica var. flava, three haplotypes for $F$. septica var. candida and three haplotypes for $F$. septica var. rufa calculated. The analyzing of the sequence from EF-1alpha (Fig. 5B) distinguished 22 haplotypes $(14 \mathrm{~F}$. septica var. flava, six $F$. septica var. candida and two $F$. septica var. rufa). The four haplotypes of $F$. septica var. flava and F. septica var. candida showed no connection to each other. The analysis of the fragment of the ITS2 region (Fig. 5C) shows relations between $F$. septica var. flava (eight haplotypes) and F. septica var. candida (four haplotypes). Here, MYX1415 shares the haplotype with representatives of the variety flava. Two haplotypes showed no relation to a different haplotype. The variety rufa has two haplotypes. The analysis of the haplotypes for the mtSSU has shown 21 haplotypes (Fig. 5D). Two haplotypes (MYX1418 and MYX1044) have no connection to another haplotype. All varieties show only connections to haplotypes of the same variety. 
A

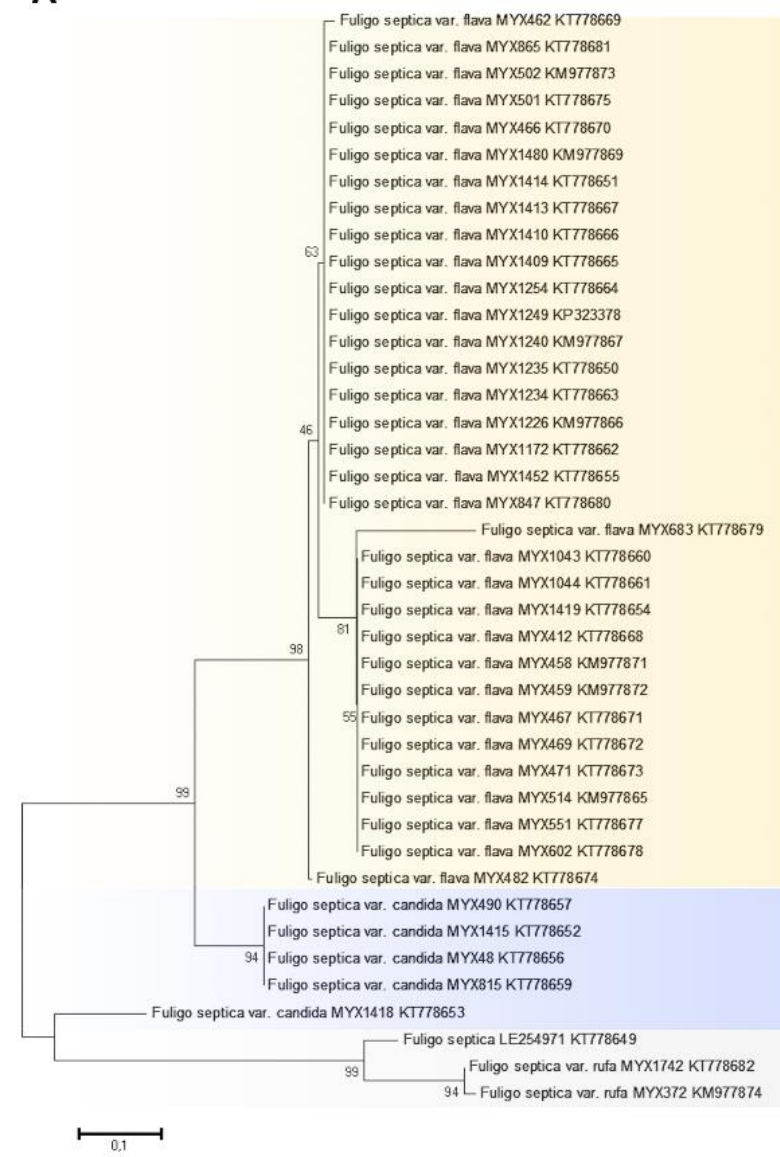

B

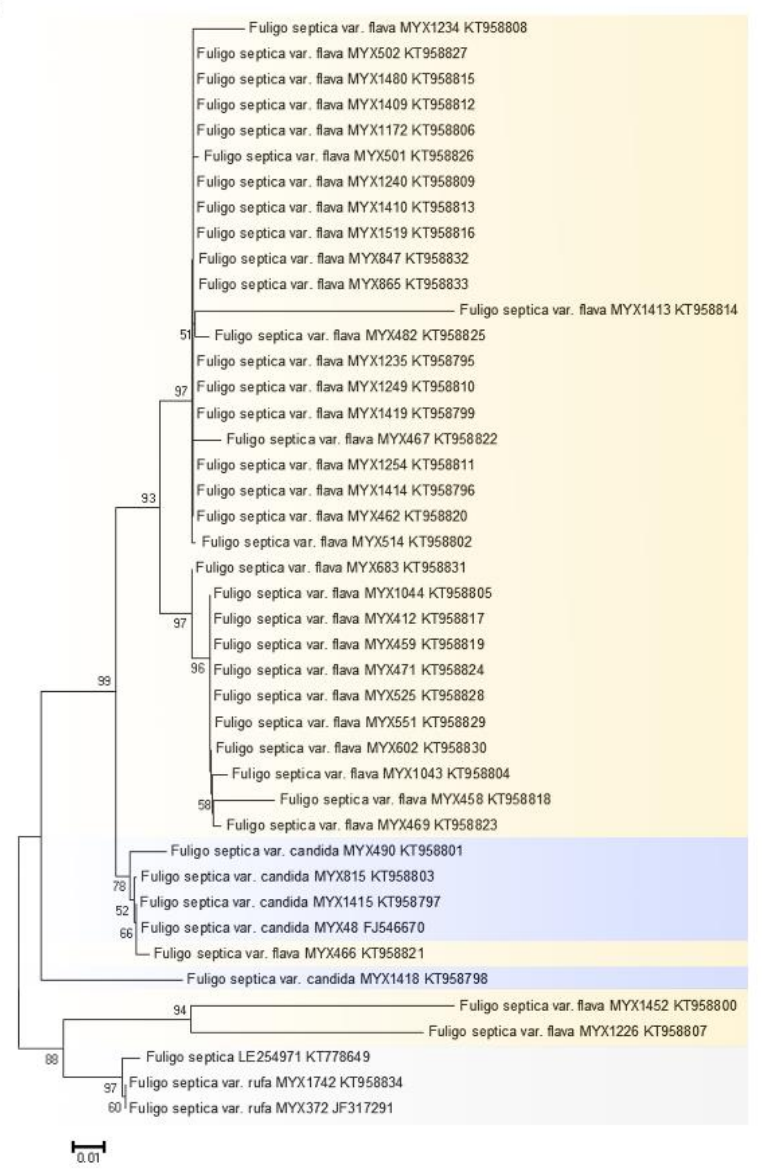

Figure 3 - Phylogenetic trees calculated with Neighbor Joining method. The percentage of replicate trees in which the associated taxa clustered together in the bootstrap test (10000 replicates) are shown next to the branches. A) phylogenetic tree based on 251 positions of partial $18 \mathrm{~S}$ rRNA sequence; B) phylogenetic tree based on 548 positions of partial EF-1alpha sequence.

The loss of pigmentation after a short storage of time was made clearly visible for all candida collections. This variety showed a significant limy cortex (single and double). In F. septica var. flava, the yellow pigment is stable for a longer time and can also be seen in older collections (sometimes only in the basal region of the cortex next to the hypothallus). The cortex of $F$. septica var. rufa is slightly reddish (not as much as in F. septica var. rosea). The cortex has at least two layers, wherein the outer carries the reddish pigment. For the studied representatives this outer cortex broke quickly after collecting from the inside layer. The varieties $F$. septica var. candida and $F$. septica var. rufa have a higher content of lime than $F$. septica var. flava. The spore diameter was measured and values between 6.7 and $9 \mu \mathrm{m}$. Here all varieties were similar to each other: $F$. septica var. flava $7.58 \mu \mathrm{m}(\mathrm{n}=1988), F$. septica var. candida $7.53 \mu \mathrm{m}(\mathrm{n}=380)$ and $F$. septica var. rufa $7.26 \mu \mathrm{m}(\mathrm{n}=270)$. The number of warts or spines on the spores was slightly smaller at $F$. septica var. candida $(0.24 \mu \mathrm{m})$ than $F$. septica var. flava $(0.29 \mu \mathrm{m})$. The number of spikes per area was for $F$. septica var. candida statistically higher (23.3 spines/ circle) than in $F$. septica var. flava (18.8 spines/ circle) and F. septica var. rufa (21.0 spines/ circle). F. septica var. candida showed less variations within the different individuals. The analysis of other characteristics such as cortex structure, number of nodes or fruiting body size showed no differences.

\section{Discussion}

Fuligo septica is a myxomycete species with conspicuous fruiting bodies. The systematic position from three varieties could be investigated by four different gene markers. All three varieties differed (except MYX1415 in ITS2, MYX1452 and MYX1226 in EF-1alpha). The 18S 
rRNA and mtSSU trees corroborate with the morphological system. The calculated concatenated tree of all four markers distinguishes these morphological varieties. The radiation events are different in each of the four calculated trees, as well as the haplotype networking analyses. After the comparison of the data for these four different markers, the markers 18S rRNA and mtSSU seems to be the most appropriate tools for the analysis of populations. In the haplotype networking analysis, with any of the markers used here, every of the individuals were placed in a relationship. This could be due to the too small range of possible genotypes. Within all analysis, the variety $F$. septica var. rufa was clearly separated from the other varieties (also in the phylogenetic trees). The 18S rRNA is relatively highly conserved, with an intron (Johansen et al. 1996, Fiore Donno et al. 2008 2013, Nandipat et al. 2012). This intron is evolving faster than the flanking elements.

ITS2 and the partial 18S rRNA are two adjacent fragments, but greatly differ from each other. The ITS2 is conserved by more than $60 \%$ and therefore can be used for species determination (Kamono \& Fukui 2006). This resulted in good discriminating ability of phylogenetically closely related individuals. However, the haploid-analysis shows no systematic relationship between the studied varieties. Only $F$. septica var. rufa is disconnected.

\section{A}

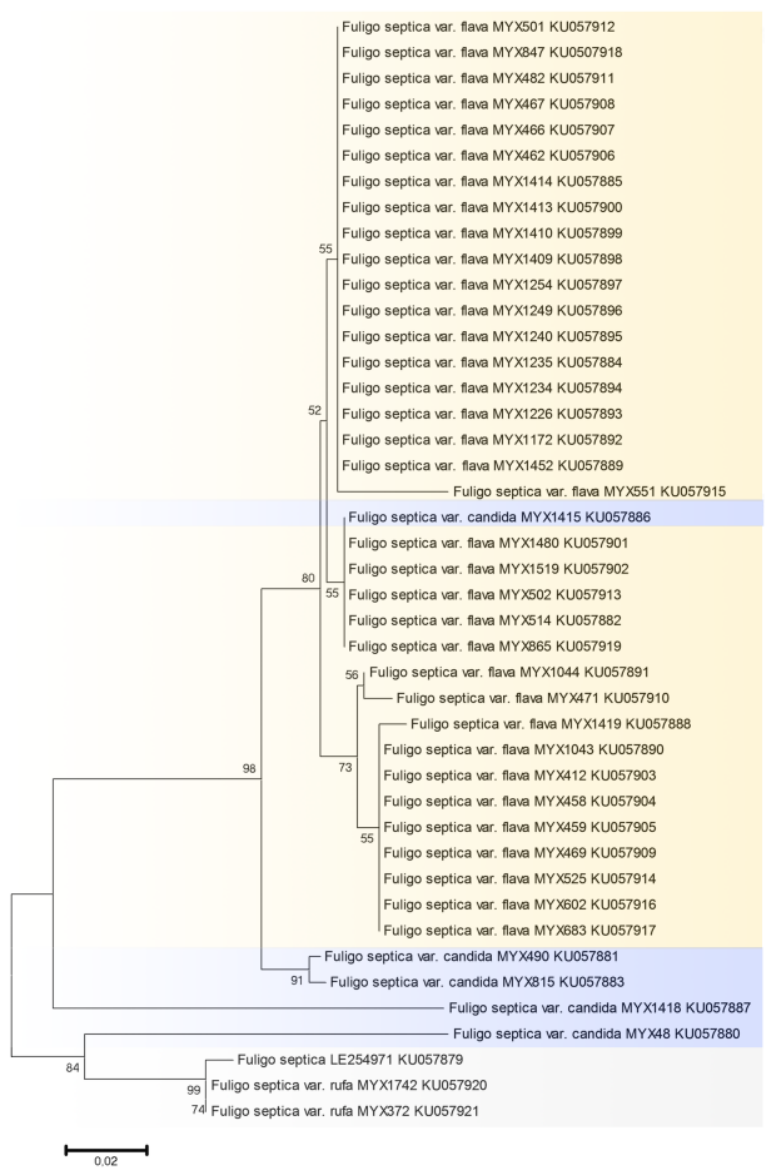

B

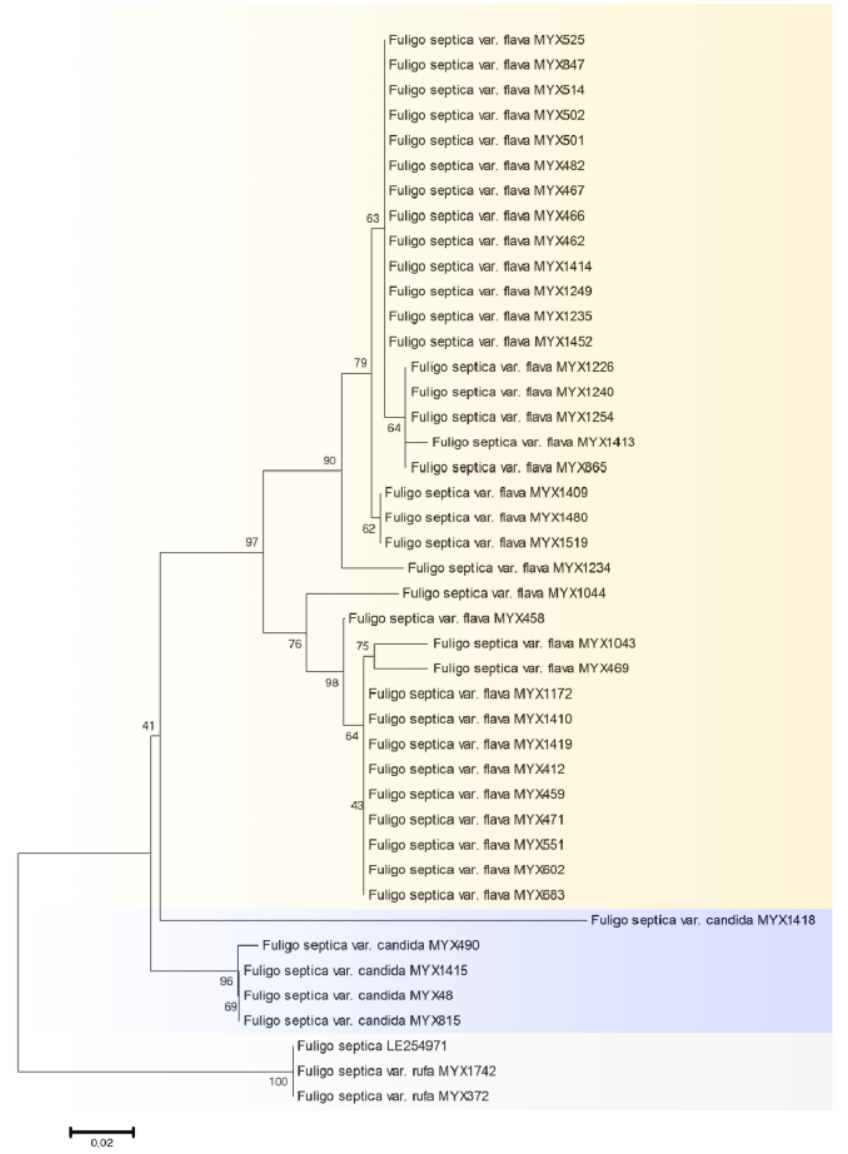

Figure 4 - Phylogenetic trees calculated with Neighbor Joining method. The percentage of replicate trees in which the associated taxa clustered together in the bootstrap test (10000 replicates) are shown next to the branches. A) phylogenetic tree based on 145 positions of a partial ITS2 sequence and B) phylogenetic tree based on 145 positions of a partial mtSSU sequence (blue $-F$. septica var. candida, yellow - F. septica var. flava, grey - F. septica var. rufa). 


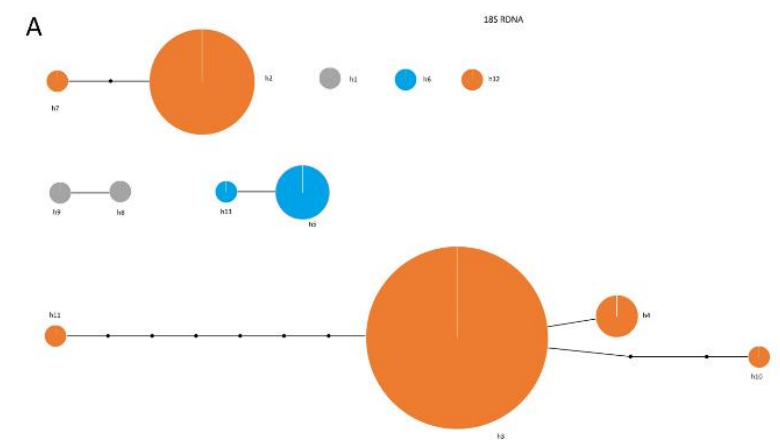

B

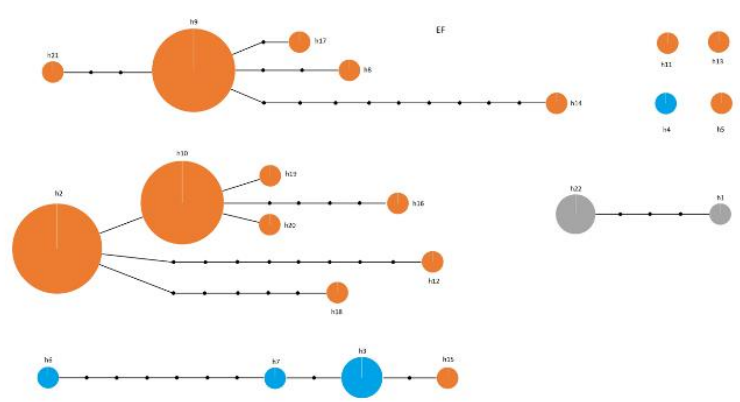

C

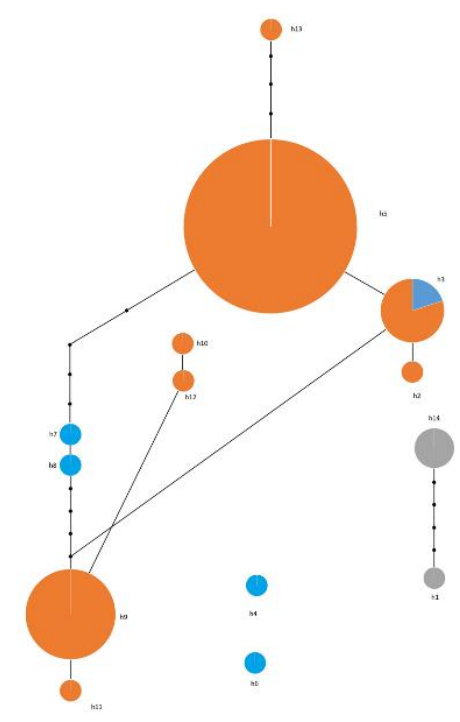

D

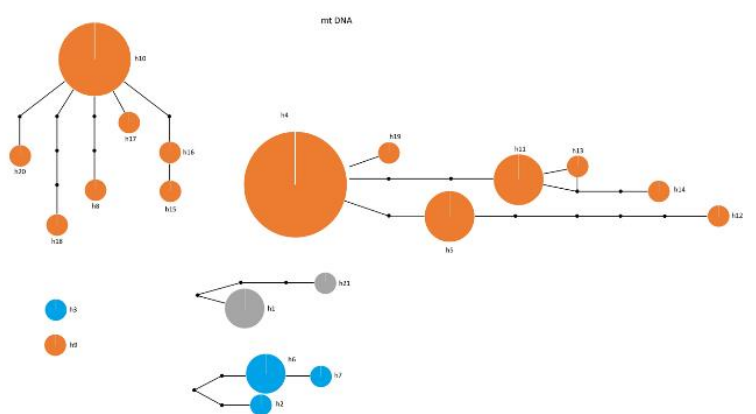

Figure 5 - The haplotype network of 43 Fuligo septica specimens. A) 18S rRNA, B) EF-1alpha, C) ITS2 and D) mtSSU (blue $-F$. septica var. candida, yellow $-F$. septica var. flava, grey $-F$. septica var. rufa).

Morphological characteristics, such as colour of peridia, size of the fruiting body, length of the stem or lime are often varying characteristics (Clark et al. 2004). In the text books, the colour of the fruiting-bodies and the nodes are major determination characters. The colour differences of the cortex could be used in most fresh collections as major feature, but appears to be a variable character (pigment loss of older collection material, influence by habitat conditions). The colouring of the lime nodes and the analysis of the spore surface is much more reliable. The features of the spore surface are seemingly less plastic. Also environmental influences have little effect on the change of these characteristics (Walker \& Stephenson 2016).

The reduction of a complex organismic system to the basis of one gene or another aspect appears to be sufficient for certain hypotheses. More characters however, should be involved for a comparative study, in order to understand as precisely as possible how different types or individuals are related to each other.

\section{References}

Baldauf SL, Doolittle WF. 1997 - Origin and evolution of the slime molds (Mycetozoa). Proceedings of the National Academy of Sciences 94, 12007-12012.

Clark J, Haskins FE, Stephenson SL. 2004 - Culture and reproductive systems of 11 species of Mycetozoans. Mycologia 96, 36-40.

Clark J, Haskins FE. 2010 - Reproductive systems in the myxomycetes: a review. Mycosphere 1, 337-353. 
Clement M, Posada D, Crandall KA. 2000 - TCS: a computer program to estimate gene genealogies. Molecular Ecology 9, 1657-1660.

El Hage N, Little C, Clark JD, Stephenson SL. 2000 - Biosystematics of the Didymium squamulosum complex. Mycologia 92, 54-64

Fiore-Donno AM, Meyer M, Baldauf SL, Pawlowski J. 2008 - Evolution of dark spored myxomycetes (slime-molds): molecules versus morphology. Molecular Phylogenetics and Evolution 46, 878-889.

Fiore-Donno AM, Clissmann F, Meyer M, Schnittler M, Cavalier-Smith T. 2013 - Two-gene phylogeny of bright-spored myxomycetes (slime moulds, superorder Lucisporidia). PlusONE 8(5): e62586. doi:10.1371/journal.pone.0062586

Hoppe T. 2013 - Molecular diversity of myxomycetes near Siegen (Germany). Mycoscience 54, 309-313.

Hoppe T, Kutschera U. 2010 - In the shadow of Darwin: Anton de Bary's origin of myxomycetology and a molecular phylogeny of the plasmodial slime molds. Theory of Biosciences 129, 15-23.

Hoppe T, Schnittler M. 2015 - Characterization of myxomycetes in two different soils by TRFLPanalysis of partial 18S rRNA gene sequences. Mycosphere 6, 216-227.

Johansen S, Muscarella DE, Vogt VM. 1996 - Insertion elements in ribosomal DNA. IN Ribosomal RNA: structure, evolution, processing and function in protein biosynthesis. Zimmermann RA, Dahlberg AE (eds). Boca Raton, FL: CRC Press, 89-108.

Kamono A, Fukui M. 2006 - Rapid PCR-based method for detection and differentiation of Didymiaceae and Physaraceae (myxomycetes) in environmental samples. Journal of Microbiological Methods 67, 496-506.

Poulain M, Meyer M, Bozonnet J. 2011 - Les Myxomycètes. Sévrier, Fédération Mycologique et Botanique Dauphiné-Savoie. France. Guide de détermination 1, 1-568. Planches 2, 1-544.

Nandipati SCR, Haugli K, Coucheron DH, Haskins E et al. 2012 - Polyphyletic origin of the genus Physarum (Physarales, myxomycetes) revealed by nuclear rDNA mini-chromosomes analysis and group I intron synapomorphy. BMC Evolutionary Biology 12, 156-166.

Neubert H, Nowotny W, Baumann K. 1995 - Die Myxomyceten Deutschlands und des angrenzenden Aplenraumes. Karlheinz Baumann Verlag, Gomaringen.

Stephenson SL. 2011 - From morphological to molecular: studies of myxomycetes since the publication of the Martin and Alexopoulos (1969) monograph. Fungal Diversity 20, 21-34.

Tamura K, Stecher G, Peterson D, Filipski A, Kumar S. 2013 - MEGA6: Molecular evolutionary genetics analysis version 6.0. Molecular Biology and Evolution 30, 2725-2729.

Walker K, Stephenson SL. 2016 - The species problem in myxomycetes revisited. Protist: 319338.

Winsett KE, Stephenson SL. 2011 - Global distribution and molecular diversity of Didymium difforme. Mycosphere 2, 135-146. 